\title{
Nasopharyngeal Obstruction: A Rare Post Laser Assisted Tonsillectomy Complication
}

\author{
K. P. Morwani, Amol Patil, Gaurav Ahluwalia* \\ Department of Otorhinolaryngology, Dr. Balabhai Nanavati Hospital, Mumbai, India \\ Email: "drgauravahluwalia@gmail.com
}

Received 19 January 2016; accepted 11 March 2016; published 14 March 2016

Copyright $@ 2016$ by authors and Scientific Research Publishing Inc.

This work is licensed under the Creative Commons Attribution International License (CC BY). http://creativecommons.org/licenses/by/4.0/

(c) (i) Open Access

\begin{abstract}
Tonsillectomy once was a most common ENT procedure, being referred in past as the "bread and butter of otorhinolaryngologists" though not so commonly performed these days. The usual complications of this procedure have been haemorrhage-primary/reactionary/secondary, infection, tonsillar bed structures injury, and even death. With the advent of newer technologies like lasers, microdebriders, coblators, harmonic scalpel, radiofrequency, newer complications also arise. This case report focuses on one such complication of laser assisted tonsillectomy, not much spoken of in books.
\end{abstract}

\section{Keywords}

Laser Assisted Tonsillectomy, Nasopharynx, Posterior Pharyngeal Wall, Palatopharyngeal Arch, Uvula

\section{Introduction}

Tonsillectomy is the single most common operation performed in Ear, Nose and Throat Department. Various methods of tonsillectomy have been practiced over the century aimed at reducing or eliminating intraoperative and postoperative morbidity. Due to various blood supplies received, intraoperative bleeding is the most difficult problem and securing it is time-consuming. The time taken to control the bleeding would invariably determine the length of operation. Common postoperative complications are bleeding and pain. Operative time and amount of blood loss are significantly reduced in the laser group. Tonsillectomy by using laser has shown less intraoperative bleeding and shortened the operative time. Total post operative pain and post operative complications were not significantly different between the two groups. In the hospital where laser machine and expertise are available, it is justifiable to use this technique as effective method of performing tonsillectomy [1].

\footnotetext{
${ }^{*}$ Corresponding author.
}

How to cite this paper: Morwani, K.P., Patil, A. and Ahluwalia, G. (2016) Nasopharyngeal Obstruction: A Rare Post Laser Assisted Tonsillectomy Complication. International Journal of Otolaryngology and Head \& Neck Surgery, 5, 84-89. 
Traditionally, tonsillectomy has been performed by means of "cold" dissection. The tonsil and its capsule are separated from the surrounding tissues using metal instruments (i.e., scissors, snare or knife). The upper pole of the tonsil is mobilized then dissection continues to the base of the tongue.

A laser-assisted tonsillectomy may describe any of the following procedures: 1) the use of a laser as a surgical tool in an otherwise standard tonsillectomy procedure; 2) the use of the laser to sequentially vaporize the tonsils in a series of outpatient visits; and 3) the use of the laser to vaporize the surface of the tonsils, i.e., a cryptolysis or a subtotal tonsillectomy. Either a hand-held carbon dioxide laser, a potassium-titanyl-phosphate laser (KTP/ 532), diode laser or an ND:YAG long pulse laser may be used [2].

A laser is used to dissect the tissue and to coagulate blood vessels. This can involve resecting the tonsillar tissue completely (laser tonsillectomy) or reducing (laser-assisted Serial tonsillectomy or laser-assisted tonsil reduction) or vaporising (laser Vaporisation tonsillectomy) the tissue [3].

\section{Case Report}

An 11-year-old boy came with history of tonsillectomy 1 year back followed by hyponasality of voice (rhinolalia clausa) and mouth breathing. On examination we found soft palate and uvula are fused with posterior pharyngeal wall, completely shutting off nasopharynx from oropharynx (Figure 1). We performed LASER surgery for him creating a somewhat natural passage, placed two soft PVC tubes one in each nostrils up to the level of uvula for 3 months to avoid synechia again. Patient post operatively regained his original voice and breaths nasally.

Patient had fused uvula and palato pharyngeal arch with the posterior pharyngeal wall following previous tonsillectomy surgery. The posterior pharyngeal wall was smooth making difficult to mark the line of fusion. Laser resistant endotracheal tube can be seen in the oral cavity.

Pre-operative investigations and anaesthetic fitness checkups were done; patient was fit for the surgery. Adequate child counselling and discussion with his parents was done about the course of management, its expected outcomes and risks involved before fetching their consent.

Figure 2 shows the pent-up thick nasal secretions due to nasal cavity ending into blind sac. Secretions were sucked out pre-operatively to see the level of obstruction nasally. Choana was found bilaterally patent, suggesting obstruction below the level of nasal cavity.

Figure 3 shows intra-operative view, hand held $\mathrm{CO}_{2}$ laser probe is seen. Neo-uvula is created, held with the babcock's forcep in the image and the palatopharyngeal arch is being created on both sides of Uvula going through the mucosal and the muscular layers.

Figure 4 shows the inflatable bulb bearing ends of the two cut pieces of the endotracheal tubes, long enough to reach the level of soft palate from the external nares were used as the nasopharygeal stents. Bulbs were inflated with air. The inflated bulbs can be seen in the image in situ.

Figure 5 shows the two cut ends of the endotracheal tubes used as stents can been seen coming out of the nares. The lengths of tubes were tailor-made as per the comfort of patient. The tubes were left in Situ for the next three months with the bulbs inflated.

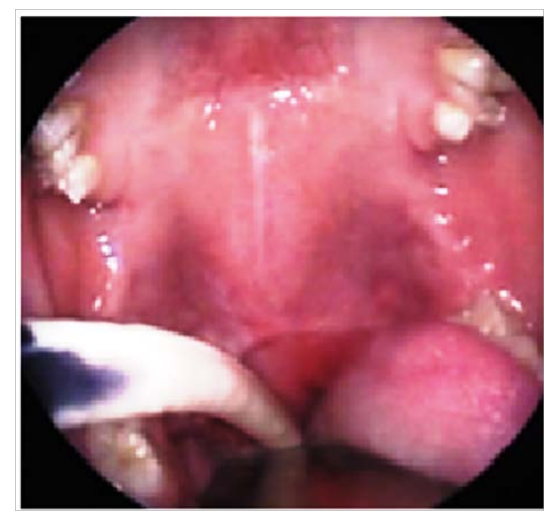

Figure 1. Pre-Operative oral cavity. 


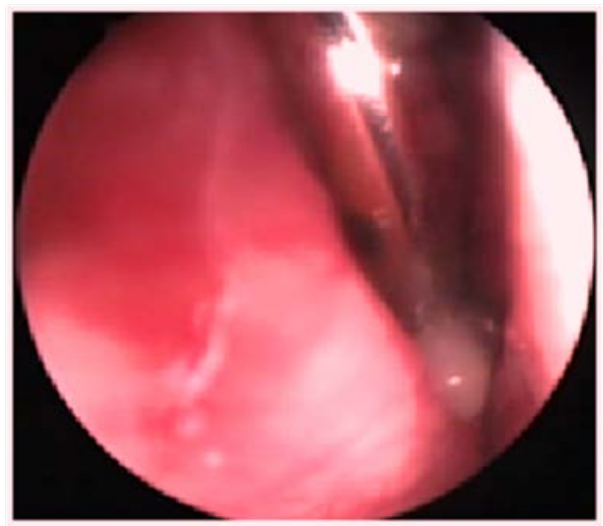

Figure 2. Pre-Operative endonasal view.

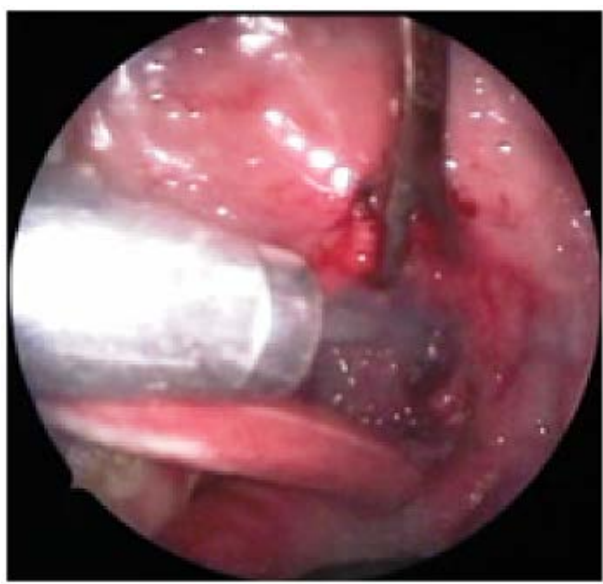

Figure 3. Intra-Operative view.

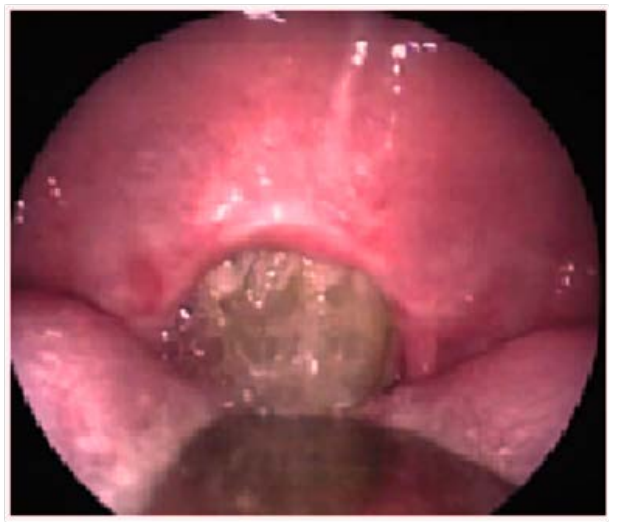

Figure 4. Nasopharyngeal stents in-situ.

Post operatively patient was kept under observation for next two days. Discharged with medications viz antibiotics, painkillers and advised for frequent OPD visits. The tubes were removed in the operating room after three months, after the deflation of bulbs. Nasal suctioning was done and nasal bleed was ruled out.

Child was kept under follow up twice a month for coming next two months then once in two months for the next six months to rule out refusion of the raw surfaces. The procedure was successful in alleviating the patient's symptoms. Patient could breathe from nose, the voice turned normal and pain subsided. There was nasal regurgitation to liquids for the first three weeks which eventually subsided. 


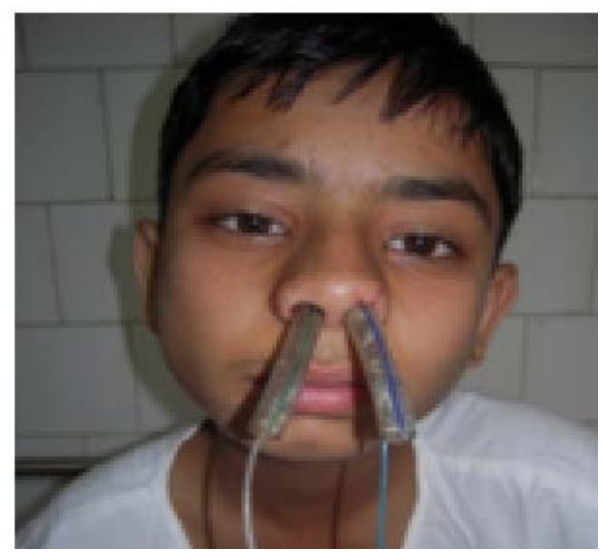

Figure 5. Post operatively with the stents in Situ.

\section{Discussion}

Complications post laser assisted tonsillectomy in various studies conducted earlier have been mentioned below in the tabulated form [3] with the intention of supporting that the above mentioned complication in this case report is a rare and unmentioned one in previous literatures.

Lasers used in tonsillectomy include $\mathrm{CO}_{2}$, KTP and contact diode lasers. Lasers both dissect tissue and coagulate blood vessels. Lasers can be used to completely resect (laser tonsillectomy), reduce (laser assisted serial tonsillectomy) or vaporise (laser vaporisation tonsillectomy) tonsillar tissue.

Five comparative studies assessed pain following laser dissection tonsillectomy [4]-[8]. In four of these studies patients treated with laser reported feeling less pain at the first postoperative assessment (usually within 24 hours) compared with those treated by cold steel dissection, but at subsequent assessments the laser group had higher pain scores than those in the cold steel group until at least 2 weeks after surgery. In the fifth study the authors noted that mean pain scores were consistently lower in the laser group. However this study included child patients, used a different laser and compared laser with diathermy.

\section{Review of literature}

\begin{tabular}{|c|c|c|c|c|}
\hline S.No & Study Details & Complications: & & \\
\hline \multirow{11}{*}{1} & \multirow{11}{*}{$\begin{array}{l}\text { Kothari et al. } \\
\text { (2002) [4], UK }\end{array}$} & Blood loss during surgery: & Postoperative haemorrhage & \\
\hline & & $\begin{array}{l}\text { KTP laser: } 20 \mathrm{ml} \\
\text { (range } 0-320 \mathrm{ml} \text { ) }\end{array}$ & KTP laser & \\
\hline & & $\begin{array}{l}\text { Dissection: } 95 \mathrm{ml} \\
\text { (range } 4-400 \mathrm{ml} \text { ) }\end{array}$ & 9 patients $(11.3 \%)$ had a 'reactionary' & \\
\hline & & $\begin{array}{l}\text { Significant difference between } \\
\text { the two }\end{array}$ & Haemorrhage. & \\
\hline & & groups $\mathrm{p}<0.001$. & $\begin{array}{l}6 \text { patients required readmission for } \\
\text { secondary haemorrhage. }\end{array}$ & \\
\hline & & & $\begin{array}{l}3 / 9 \text { patients needed to have further surgery } \\
\text { to control the bleeding. }\end{array}$ & \\
\hline & & & Dissection: & \\
\hline & & & $\begin{array}{l}4 \text { patients }(5.5 \%) \text { had minor 'reactionary' } \\
\text { bleeding. }\end{array}$ & \\
\hline & & & $\begin{array}{l}3 \text { patients required readmission for } \\
\text { secondary haemorrhage. }\end{array}$ & \\
\hline & & Reasons & KTP & Dissection \\
\hline & & Bleeding & 9 & 4 \\
\hline
\end{tabular}




\section{Continued}

\begin{tabular}{|c|c|c|c|c|}
\hline & & Return to theatre & 3 & 0 \\
\hline & & Pain & 12 & 13 \\
\hline & & Vomiting & 13 & 16 \\
\hline & & Blood in vomit & 7 & 9 \\
\hline & & Anaesthetic & 3 & 5 \\
\hline & & $\begin{array}{l}\text { Patients unhappy about } \\
\text { discharge }\end{array}$ & 4 & 14 \\
\hline \multirow[t]{5}{*}{2} & $\begin{array}{l}\text { Auf } \\
\text { et al. (1997) [5], } \\
\text { UK }\end{array}$ & KTP laser: $20 \mathrm{ml}$ & KTP laser, out of 38 patients & \\
\hline & & Dissection: $52 \mathrm{ml}$ & 0 patients had a primary haemorrhage. & \\
\hline & & $\begin{array}{l}\text { Significant difference between } \\
\text { the two } \\
\text { Groups } p<0.01 \text {. }\end{array}$ & $\begin{array}{l}6 \text { patients had a secondary haemorrhage of } \\
\text { whom } 2 / 6 \text { patients required readmission } \\
\text { (but not surgery). }\end{array}$ & \\
\hline & & & Dissection: & \\
\hline & & & $\begin{array}{l}\text { No primary or second haemorrhage was } \\
\text { observed in any patient. }\end{array}$ & \\
\hline 3 & $\begin{array}{l}\text { D'eredita and } \\
\text { Marsh (2004) [6], } \\
\text { USA }\end{array}$ & $\begin{array}{l}\text { Minimal for both groups } \\
\text { (around } 5 \mathrm{ml} \text { ). }\end{array}$ & $\begin{array}{l}\text { Authors report that in both groups no early } \\
\text { haemorrhage occurred during the first } 24 \text { hours } \\
\text { and no late haemorrhage was reported } \\
\text { by parents during follow-up. }\end{array}$ & \\
\hline \multirow[t]{8}{*}{4} & $\begin{array}{l}\text { Strunk and } \\
\text { Nichols (1990) } \\
\text { [7], USA }\end{array}$ & KTP laser: 17.65 ml & $\begin{array}{l}\text { There were no occurrences of primary } \\
\text { haemorrhage. }\end{array}$ & \\
\hline & & Dissection: $58.59 \mathrm{ml}$ & & \\
\hline & & $\begin{array}{l}\text { Significant difference between } \\
\text { the two }\end{array}$ & Secondary haemorrhage & \\
\hline & & Groups $\mathrm{p}<0.01$ & $\begin{array}{l}\text { KTP laser: } 1 \text { (24) patient had a secondary } \\
\text { haemorrhage, which resolved after chemical } \\
\text { cautery. }\end{array}$ & \\
\hline & & & $\begin{array}{l}\text { Dissection: } 1 \text { (37) one patient had secondary } \\
\text { haemorrhage, which resolved } \\
\text { spontaneously. }\end{array}$ & \\
\hline & & & $\begin{array}{l}\text { Left laser: } 1 \text { patient had a secondary } \\
\text { haemorrhage on the right dissection site, } \\
\text { which required operative cautery. }\end{array}$ & \\
\hline & & & $\begin{array}{l}\text { Right laser: No secondary haemorrhage } \\
\text { events were observed }(0 / 10) \text {. }\end{array}$ & \\
\hline & & & $\begin{array}{l}\text { One patient in the laser group needed suture } \\
\text { ligature to control bleeding. }\end{array}$ & \\
\hline \multirow[t]{4}{*}{5} & $\begin{array}{l}\text { Saito, Honda and } \\
\text { Saito (1999) [8], } \\
\text { Japan }\end{array}$ & $\begin{array}{l}\text { Authors note that intraoperative } \\
\text { blood loss }\end{array}$ & 1 patient developed a secondary & \\
\hline & & $\begin{array}{l}\text { was dramatically reduced with } \\
\text { the use of the }\end{array}$ & haemorrhage on the conventional side & \\
\hline & & KTP laser. & 9 days after surgery. & \\
\hline & & Postoperative bleeding: & & \\
\hline
\end{tabular}




\section{Continued}

\begin{tabular}{|c|c|c|c|}
\hline 6 & $\begin{array}{l}\text { Oas and Barteles } \\
\text { (1990) [9], UK }\end{array}$ & $\begin{array}{l}\text { There were no patients with } \\
\text { haemorrhage on the laser surgery } \\
\text { side. } \\
\text { Less blood loss with laser } \\
\text { tonsillectomy. }\end{array}$ & \\
\hline 7 & $\begin{array}{l}\text { Krespi [10], New } \\
\text { York, USA }\end{array}$ & $\begin{array}{l}\text { No peri-operative or } \\
\text { anaesthesia-related } \\
\text { complications }\end{array}$ & $\begin{array}{l}1 \text { secondary haemorrhage which occurred } \\
\text { on the laser side on fifth postoperative day. }\end{array}$ \\
\hline 8 & $\begin{array}{l}\text { Remacle et al. } \\
\text { [11], } \\
\text { Belgium }\end{array}$ & $\begin{array}{l}\text { No early or delayed bleeding } \\
\text { the dissection side } \\
\text { monopolar electrocautery was } \\
\text { required for } \\
\text { two patients. }\end{array}$ & $\begin{array}{l}\text { No second time surgery has been necessary } \\
\text { for bleeding control. }\end{array}$ \\
\hline
\end{tabular}

\section{Conclusions}

Nasopharyngeal obstruction (i.e. fusion of uvula and palatopharyngeal arch with the posterior pharyngeal wall) stands as a rare late complication of laser assisted tonsillectomy. Most probably this seems to be a result of poor surgical techniques or inadequate training of laser surgery by the previous operating surgeon causing inadvertent uvular and palatopharyngeal arch, posterior pharyngeal wall injury and edema leading to synechia of the raw surfaces.

So, adequate training of laser surgery is a must before attempting such procedures as recommended in most of the case studies done previously and also in the nice guidelines.

Another point of discussion in this case is the critical time interval for removal of the nasopharyngeal stent avoiding re-fusion of the raw surfaces. In this case we kept the stent for 3 months and the result in long term was acceptable.

\section{References}

[1] Ishlah, L.W., Fahmi, A.M. and Srinovianti, N. (2005) Laser versus Dissection Technique of Tonsillectomy. The Medical Journal of Malaysia, 60, 76-80.

[2] Blue Cross of Idaho Website.

[3] Tonsillectomy Using Laser, National Institute for Health and Clinical Excellence, July 2006.

[4] Kothari, P., Patel, S., Brown, P., et al. (2002) A Prospective Double-Blind Randomized Controlled Trial Comparing the Suitability of KTP Laser Tonsillectomy with Conventional Dissection Tonsillectomy for Day Case Surgery. Clinical Otolaryngology \& Allied Sciences, 27, 369-373. http://dx.doi.org/10.1046/j.1365-2273.2002.00596.x

[5] Auf, I., Osborne, J.E., Sparkes, C., et al. (1997) Is the KTP Laser Effective in Tonsillectomy? Clinical Otolaryngology \& Allied Sciences, 22, 145-146 http://dx.doi.org/10.1046/j.1365-2273.1997.d01-305.x

[6] D'Eredita, R. and Marsh, R.R (2004) Contact Diode Laser Tonsillectomy in Children. Otolaryngology—Head \& Neck Surgery, 131, 732-735. http://dx.doi.org/10.1016/j.otohns.2004.04.031

[7] Strunk, C.L. and Nichols, M.L. (1990) A Comparison of the KTP/532-Laser Tonsillectomy vs. Traditional Dissection/ Snare Tonsillectomy. Otolaryngology—Head \& Neck Surgery, 103, 966-971.

[8] Saito, T., Honda, N. and Saito, H. (1999) Advantage and Disadvantage of KTP-532 Laser Tonsillectomy Compared with Conventional Method. Auris, Nasus, Larynx, 26, 447-452. http://dx.doi.org/10.1016/S0385-8146(99)00025-5

[9] Oas Jr., R.E. and Bartels, J.P. (1990) KTP-532 Laser Tonsillectomy: A Comparison with Standard Technique. Laryngoscope, 100, 385-388. http://dx.doi.org/10.1288/00005537-199004000-00010

[10] Krespi, Y.P. and Ling, E.H. (1994) Laser-Assisted Serial Tonsillectomy. Journal of Otolaryngology, 23, 325-327.

[11] Remacle, M., Keghian, J., Lawson, G., et al. (2003) Carbon-Dioxide Laser-Assisted Tonsi Ablation for Adults with Chronic Tonsillitis: A 6-Month Follow-Up Study. European Archives of Oto-Rhino-Laryngology, 260, 456-491. http://dx.doi.org/10.1007/s00405-003-0600-4 